\title{
拡散性に著しい差のある金属間の 相互拡散
}

\section{一俣野の方法が破綻するとき—}

\section{飯 島 嘉 明*}

\section{1. はじめに}

ある温度に扮ける相互拡散係数は濃度にの及依存する物性 値であると理解されている.2 元合金におけ打相互拡散係数 を決定するには，たと光ば金属 A と金属 B の円柱状試料の 平坦面を接合して, 高温で拡散させた後, 拡散領域の濃度分 布に俣野の方法 ${ }^{(1)}$ を用いて算出する。濃度分布の測定には現 在は EPMA 利用するのが一般的であるが，その利用は 1960年代からであり，それ以前は化学分析によるものが多 い. 相互拡散保数を固有拡散係数や自己拡散係数に結びつけ る式は Darken によって1948年に提出され(2)，その妥当性は 1950年代に示されている(3). しかし, 最近の拡散実験技術 の進歩によって相互拡散係数が精密に決定されるに伴い, 相 互拡散の解析法に問題のあることが指摘されている。特に, 拡散性汇著しい差のある金属間の相互拡散沈いてては矛盾点 も明確である。これに関する最近の研究を紹介したい。

\section{2. 相互拡散係数が拡散対に依存する実験例}

拡散係数 $D$ は拡散の基本則として知られている Fick の第 1 法則に执いて定義される。

$$
J=-D \frac{\partial C}{\partial x}
$$

ここで, $J$ は流束, $C$ は濃度, $x$ は距離である。この式は Fick が1855年に提案し, 水溶液中の塩の拡散実験により実 際に成立することが示された。この場合のように拡散速度が
大きく, 定常状態が成立している場合には, 流束と濃度勾配 から式 (1) より拡散係数を決定することができる.しかし, 固体金属中の通常の拡散実験では定常状態が実現されること は活とんどなく, ある時間拡散させた後の濃度プロファイル の解析から拡散係数を求めるのが一般的である. その場合, 連続の式として

$$
\frac{\partial C}{\partial t}=-\frac{\partial J}{\partial x}=\frac{\partial}{\partial x}\left(D \frac{\partial C}{\partial x}\right)
$$

と表されるのが Fick の第 2 法則である. 式 (2)に怙いて拡 散係数が距離 $x$ に依存しないならば,

$$
\frac{\partial C}{\partial t}=D \frac{\partial^{2} C}{\partial x^{2}}
$$

の上らに表される，純金属の自己拡散や濃度の均一な合金中 の拡散の場合は式 ( 3 )を境界条件の下で解く.

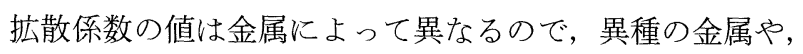
濃度の大きく異なる合金を接合した拡散対においては拡散領

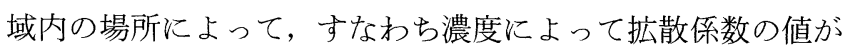
異なると考光るのが自然である。このように，相互拡散の場 合は非定常状態汶対応する Fick の第 2 法則である式 (2) 亿 適当な境界条件を与兄て解を得なければならない。しかし， 式 (2)の偏微分方程式を解析的に解くことはできない，そ

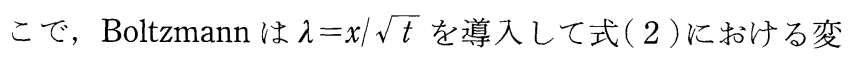
数を 1 個減じた。ささらに, 俣野がいわゆる俣野面を

$$
\int_{C_{1}}^{C_{2}} x \mathrm{~d} C=0
$$

によって定義することによって, 四式解法を得た(1)。すなわ ち，拡散対が濃度 $C_{1}$ の合金と $C_{2}$ の合金から構成されてい

* 東北大学教授; 大学院工学研究科材料物性学専攻 (予980-8579 仙台市青葉区荒巻字青葉02)

Diffusion Between Metals of Very Different Diffusional Properties, -Unapplicable Case of Matano's Method-; Yoshiaki Iijima (Department of Materials Science, Graduate School of Engineering, Tohoku University, Sendai)

Keywords: Ficks's law, Matano's method, Darken's relation, interdiffusion, diffusivity, vacancy flux, retardation, gold-iron alloy, gold-nickel alloy, high hydrogen pressure

2001年 6 月 18 日受理 
る場合，任意の濃度 $C_{\mathrm{i}}$ に括外る相互拡散係数 $\tilde{D}\left(C_{\mathrm{i}}\right)$ は次式 のように与えられる。

$$
\tilde{D}\left(C_{\mathrm{i}}\right)=-\frac{1}{2 t}\left(\frac{\mathrm{d} x}{\mathrm{~d} C}\right)_{C=C_{\mathrm{i}}} \int_{C_{\mathrm{i}}}^{C_{1}} x \mathrm{~d} C
$$

これによって, 拡散領域の濃度一距離曲線から, 濃度に依存 する相互拡散係数を決定することが可能になった，俣野の論 文は1933年に発表され，それ以来，相互拡散の解析には俣 野の方法，あるいは Boltzmann-Matano の方法と呼ばれて， 今日まで広く使われている。式(1)から（５）飞至る俣野の 論文の内容は最近, 小岩によって詳しく解説されている(4). しかし, 俣野の論文では拡散に伴ら拡散領域の体積変化が考 慮されていなかったので，その後，Sauer とFreise(5)がこれ に対する補正の方法を1962年に発表している. Smigelskas と Kirkendall ${ }^{(6)}$ が1947年に発見したマーカーの移動は，拡 散対の中では A, B 両原子がそれぞれ固有の拡散倸数を持っ て空孔を介して移動していることを示している．1948年に Darken ${ }^{(2)}$ は，相互拡散係数とマーカー移動速度から，濃度 勾配下の両原子の拡散係数である固有拡散俰数を求める方法 を発表した。ささらに固有拡散係数 $D$ と自己拡散係数 $D^{*}$ と の関係式も導出した，すなわち，A-B 2 元合金の A のモル 分率 $N_{\mathrm{A}}$ に和村る相互拡散係数 $\tilde{D}\left(N_{\mathrm{A}}\right)$ は次のよらに表され る.

$$
\begin{aligned}
\tilde{D}\left(N_{\mathrm{A}}\right) & =N_{\mathrm{B}} D_{\mathrm{A}}\left(N_{\mathrm{A}}\right)+N_{\mathrm{A}} D_{\mathrm{B}}\left(N_{\mathrm{A}}\right) \\
& =\left\{N_{\mathrm{B}} D_{\mathrm{A}}^{*}\left(N_{\mathrm{A}}\right)+N_{\mathrm{A}} D_{\mathrm{B}}^{*}\left(N_{\mathrm{A}}\right)\right\} \phi\left(N_{\mathrm{A}}\right)
\end{aligned}
$$

ここで， $\phi$ 熱力学的因子と呼ばれ，合金の理想固溶体から

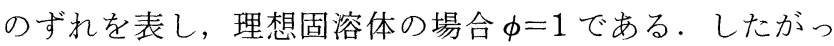
て, 均一濃度合金中の成分原子の拡散係数である自己拡散係 数に熱力学的因子を乗じたものが濃度勾配下の拡散を表す固 有拡散係数を与える. 結局, 相互拡散係数と呼ばれているも のは $\mathrm{A}, \mathrm{B}$ 両原子の拡散ならびにそれらの移動速度の差に上 って生ずる空孔の流れのすべてを総合した結果としての拡散 対中での濃度変化の仕方を表すものである.

Darken の関係式に対しては, その後, 空孔流の補正が必 要であることが Manning ${ }^{(7)}$ や Heumann ${ }^{(8)}$ とよって示され た。また，体積变化を伴ら拡散に拈ける俣野面についての詳 細な検討が孫と佐野によってなされた ${ }^{(9)}$ ，さらに体積変化を 伴う場合の座標系に関して，モル基準座標の提案が大西と 下㟝によってなされた ${ }^{(10)}$ 。こうした研究をもとに，数多く の 2 元系合金の相互拡散係数と固有拡散係数扰よびそれら の温度依存性が実験的に決定されてきたが，解析方法の基本 を再検討させるような重要な問題点が指摘されることはこれ まで活とんどなかった，例えば，カーケンドールボイドの生 成はボイドゾーンの密度減少をもたらし, 濃度プロファイル を延長させるのので, 相互拡散係数を見かけ上増大させる。し かし, ボイドが生成しない程度に圧力をかけて, 濃度一距離 曲線が正常に得られれば, 相互拡散係数の值は添ぼ正しく得 ら机る(11)(12)

しかしながら，拡散領域に異相界面が存在すると，事態は 全く変わる場合がある。図 1 は $\gamma-\mathrm{TiAl}$ 合金と純 $\mathrm{Ti}$ との拡 散対から得られた相互拡散係数(○印) と $\beta$ - Ti 相内の単相

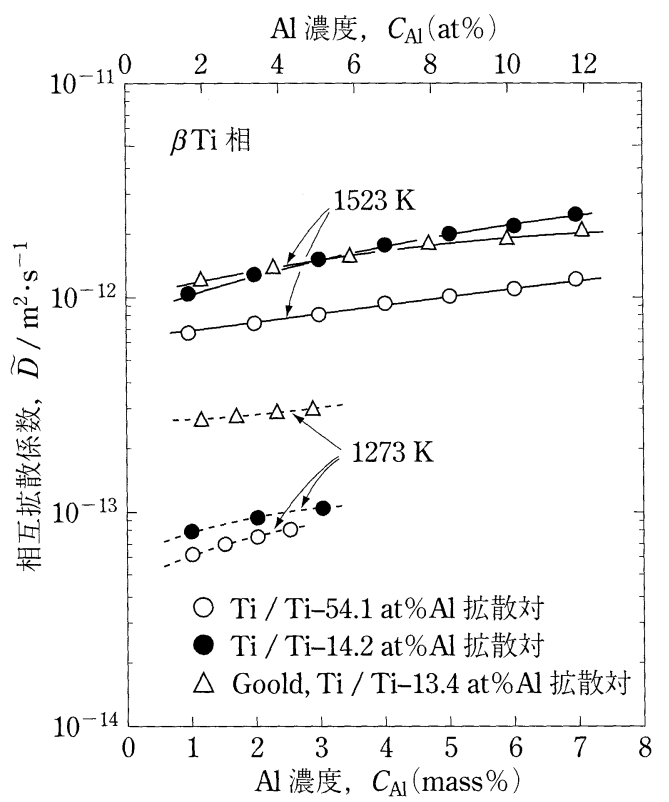

図 1 Ti-Al 系の三種類の拡散対から決定した $\beta$ 相中 に扣沙る相互拡散係数の濃度依存性.

拡散対から得られたもの(印) とを比較したものであ

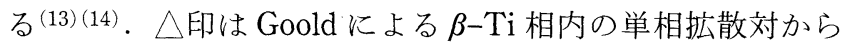
得られたものである。純 Ti が $\beta$ 相である $1523 \mathrm{~K}$ とおいて ○と $\triangle$ は良く一致しているが，○はこれらの值よりも明らか に小さい. $1273 \mathrm{~K}$ に执いても○はのよりる小い。ただし， 崔これらより大きいが，Goold は拡散対をバット溶接法に よって接合しており，接合時に生じた拡散による影響がある ものとされている。このように, 単相拡散対を用いて得られ た相互拡散保数の值と多相拡散対を用いて得られた相互拡散 係数の值には明らかな相違が認められる。このような不一致 は $\mathrm{Ag}-\mathrm{Zn}$ 系(15) および $\mathrm{Ag}-\mathrm{Cu}$ と $\mathrm{Au}-\mathrm{Pt}$ 系(16) の相互拡散に おいても見いだされている。Jost によれば(17)(18)，拡散領域 飞異相界面が存在する場合にも，俣野の方法は適用できるこ とになっているが，現実には合金系によっては相互拡散係数 が一致しないといら矛盾が生じる。さらにこの Ti-Al 合金 系に拈いて， $\beta$ 相と $\gamma$ 相との拡散対ではマーカーは $\beta$ 相内に あって Ti 飞富む側飞移動し， $\beta$ 単相拡散対では $\mathrm{Al}$ 亿富む側 に移動した．したがって，固有拡散係数の大小関係は拡散対 によって逆転することになり, Darkenの解析を多相拡散対 に用いるには限界があることを示している。この他，多相拡 散対の異相界面濃度が平衡状態図に示された濃度と異なる場 合があることも指摘されている(13)(14)。西澤と千葉は多相拡 散に括ける特異な問題を界面抵抗によって説明しょうとした が(19)，界面化偏析や第 3 相が存在しない限り界面抵抗の存 在は考光にくい。

$\mathrm{Ti}-\mathrm{Al}$ 系の拡散をある一つの温度で比較すれば， $\beta$ - $\mathrm{Ti}$ 相 は拡散が極めて速い相であり， $\gamma$ - TiAl 相は拡散が非常に遅 い相である。このように，拡散対を構成する金属間の拡散性 が著しく異なる場合に，多相拡散対の特異性が現れやすい上 亏と思わ机る。 $\beta-\mathrm{Ti} / \gamma-\mathrm{TiAl}$ 拡散対は純金属と金属間化合物 
との拡散対である.著者らは金属間化合物に伴う複雑さを避 けるために, 純金属と純金属との拡散対で拡散性に著しい差 異のあるものとして $\mathrm{Au}-\mathrm{Fe} 2$ 元系に着目し, 拡散研究を行 ってきた (14)(20). それから得られた結果を次に紹介寸る.

\section{3. $\mathrm{Au}-\mathrm{Fe} 2$ 元合金の相互拡散}

$\mathrm{Au}-\mathrm{Fe} 2$ 元系は図 2 の状態図に示されるよらに, $\mathrm{Au}$ に富 む側に広い濃度および温度範囲にわたって固溶体を形成す る. 他方, Fe に富む側では $\alpha$ 相固溶体の濃度幅は狭く, $\gamma$ 相固溶体ではやや広い。 また， $\alpha$ 相には磁気変態がある。し たがって, Auに富む固溶体域内で単相拡散対を構成するこ とも容易であり，また， $\mathrm{Au}$ 相固溶体と $\mathrm{Fe}$ 相固溶体との拡 散対により, 中間相を生成することなく, 異相界面を 1 枚 有する拡散対を構成することができる。 Ti-Al 系では $\gamma$ 相は

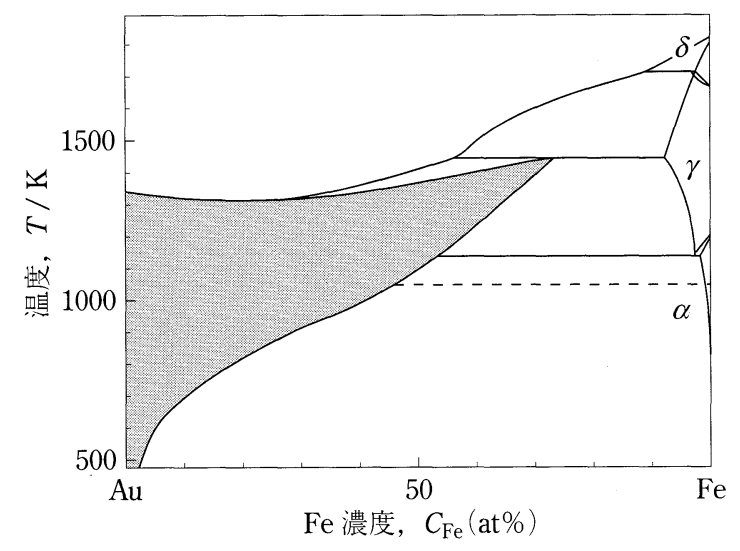

図 $2 \mathrm{Au}-\mathrm{Fe}$ 系平衡状態図.

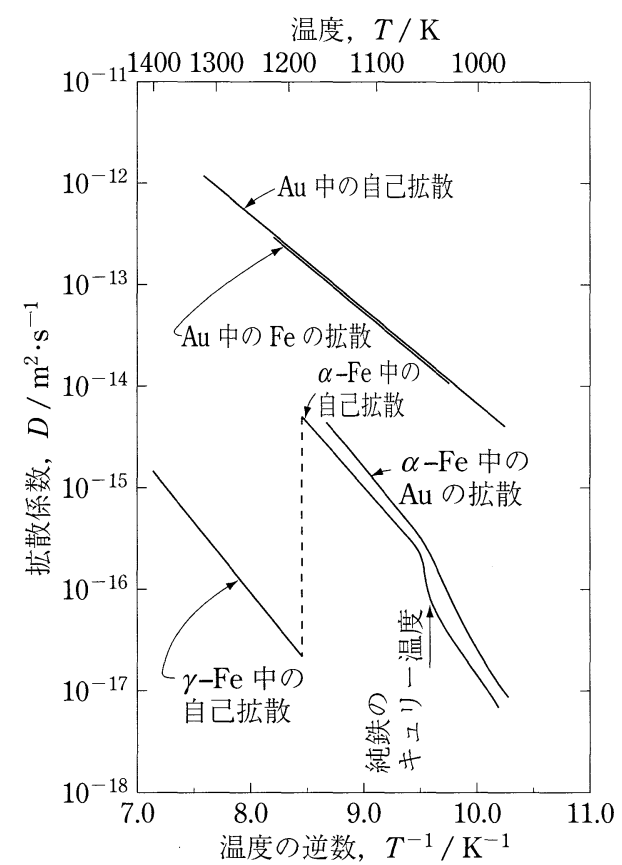

図 $3 \mathrm{Au}$ 抢よびFe 中に拈けるトレーサー拡散係数の 温度依存性.
金属間化合物であったが， $\mathrm{Au}-\mathrm{Fe}$ 系では $\gamma$ 相は固溶体であ るので, 拡散機構に抢ける複雑さを避けることがでさる. 図 3 は $\mathrm{Au}-\mathrm{Fe}$ 系に挑けるトレーサー拡散係数のアレニウスプ ロットを示したものである， $\gamma-\mathrm{Fe}$ の自己拡散係数に比べる と, $\mathrm{Au}$ の自己拡散係数は約 4 桁大きい. $\alpha-\mathrm{Fe}$ ではその差 は 1 桁半であるが， $\alpha-\mathrm{Fe}$ の強磁性温度域になるとその差は 低温ほど大きくなっていく。したがって，拡散対の構成とそ の拡散温度によって両端の拡散係数の差異の幅を適宜選定す ることが可能である。

図 4 は $\mathrm{Au} / \mathrm{Fe}$ 拡散対を用いて得られた相互拡散係数 $\tilde{D}$ の 濃度依存性を示したものである(14)(20)。約 15 at\% Auに最大 值を示しており，その形は温度に汪とんど依存しない。約 15 at \% Au に最大值を示すことは状態図の固相線の形から予 測される通りである。ここで注目すべき点は相互拡散係数を $\mathrm{Fe}$ 濃度ゼロに外挿した值と $\mathrm{Au}$ 中の $\mathrm{Fe}$ のトレーサー拡散係 数 $D_{\mathrm{Fe}}^{*}$ との対応である. 式 $(7)$ に示した Darken の関係式に よれば，これらの值は一致すべきものである。1048から $1171 \mathrm{~K}$ までの $\mathrm{Au} / \alpha-\mathrm{Fe}$ 拡散対では相互拡散係数を $\mathrm{Fe}$ 濃度 ゼロに外挿した值と $\mathrm{Au}$ 中の $\mathrm{Fe}$ の拡散係数 $D_{\mathrm{Fe}}^{*}$ の值は期待 される通り一致している.しかしながら，1193 K 以上およ び $1023 \mathrm{~K}$ 以下の温度領域では相互拡散係数の值は $\mathrm{Au}$ 固溶 相の濃度範囲全体にわたって低下し, $\mathrm{Au}$ 中の Fe の拡散係 数の值に一致しなくなる。このようにDarkenの関係式が， ある 2 元系合金拡散対の拡散温度によって, 一致したり, 一致しなくなったりする例はこれまでに知られていなかっ た. $\mathrm{Au} / \mathrm{Fe}$ 拡散対においては $1193 \mathrm{~K}$ 以上で $\mathrm{Fe}$ は $\gamma$ 相とな り, $1023 \mathrm{~K}$ 以下では Fe は強磁性領域に入る。したがって,

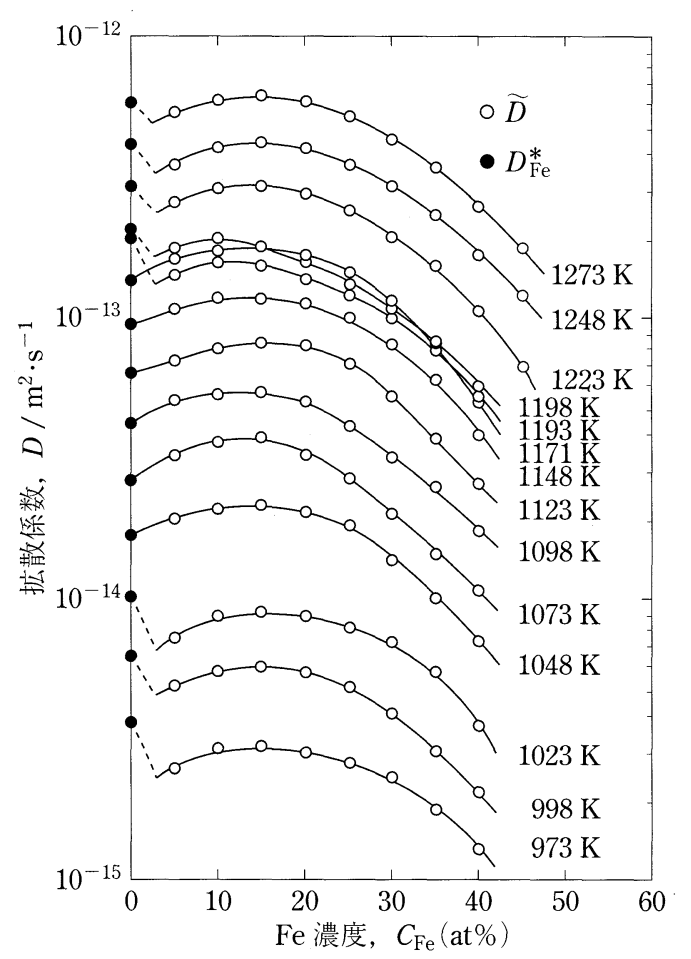

図 $4 \mathrm{Au} / \mathrm{Fe}$ 拡散対から決定された相互拡散係数の濃 度依存性。 


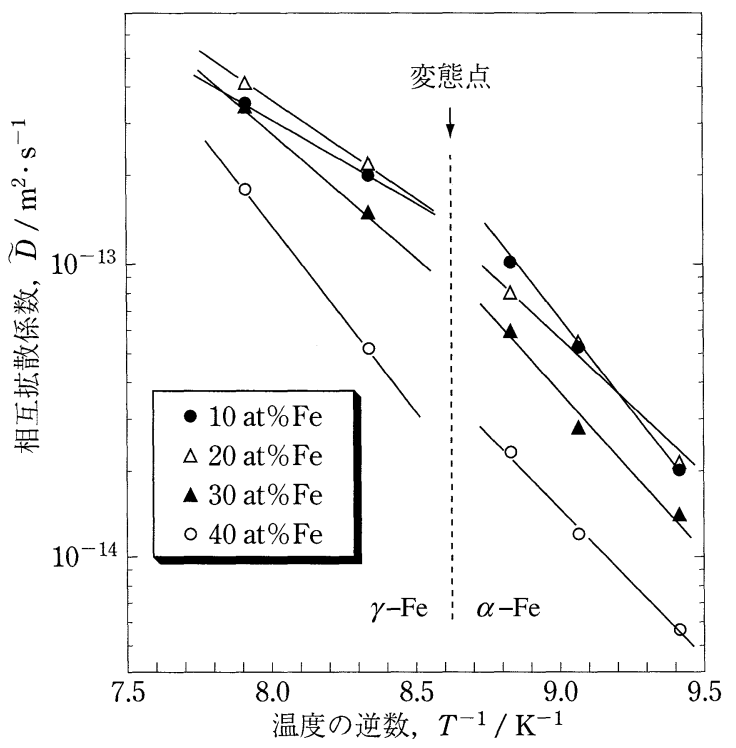

図 $5 \mathrm{Au} / \mathrm{Fe}$ 拡散対の $\mathrm{Au}$ に富む相に括ける相互拡散 係数の温度依存性.

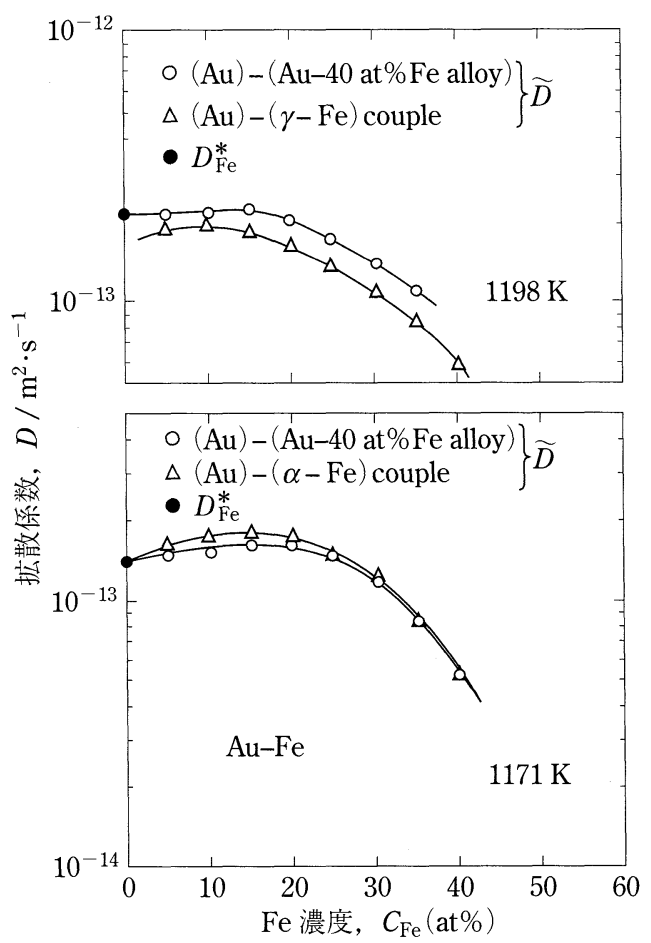

図 6 二つの異なる $\mathrm{Au}-\mathrm{Fe}$ 系拡散対から決定された相 互拡散係数の濃度依存性.

Darkenの関係式が成立しなくなる理由は Fe 側の拡散係数 が著しく低下することによるものと考光ざるを得ない．

図 4 に示した相互拡散係数をアレニウスプロットすると, 図 5 のようになり，Au に富む固溶相の相互拡散係数の温度 依存性が $\mathrm{Fe}$ 側の $\alpha-\gamma$ 相変態温度を境に不連続となり, 明ら かに Fe 側の拡散性の影響を受けている。 ある相の相互拡散 係数がこのように隣りの相の拡散性の影響を強く受けること は極めて奇異なことであり, 相互拡散係数が濃度のみに依存
する物性值であるとする理解に矛盾し，俣野の方法の破綻を 示すものである.

図 6 は $\mathrm{Au}$ に富む固溶相内で拡散対を構成して1171およ び $1198 \mathrm{~K}$ に拉いて $\mathrm{Au} / \mathrm{Fe}$ 拡散対の場合と相互拡散係数の 值を比較したものである. $1171 \mathrm{~K}$ では両者は一致するが， 1198 K では一致しない。すなわち, Au 側固溶相の単相拡 散対の相互拡散係数を $\mathrm{Fe}$ 濃度ゼ口に外插した值は $\mathrm{Au}$ 中の $\mathrm{Fe}$ の自己拡散係数 $D_{\mathrm{Fe}}^{*}$ の值に期待される通り一致している が, $\mathrm{Au} / \mathrm{Fe}$ 拡散対では一致するか否かは $\mathrm{Fe}$ 側の拡散性に依 存する. 要するに, $\mathrm{Au} / \alpha-\mathrm{Fe}$ 拡散対のように拡散対を構成 する金属間の拡散性に著しい相違がなければ，異相界面を含 む拡散対に扣いても Darkenの関係式は大凡成立するが， $\mathrm{Au} / \gamma-\mathrm{Fe}$ のように 4 桁もの拡散性の著しい差異がある場合 は Darkenの関係式は成立し得ないと考㝋られる。

\section{4. マルチプルマーカー法を用いた $\mathrm{Au}-\mathrm{Fe}$ 系の固有 拡散係数の決定}

相互拡散係数の值が拡散対の構成によって異なる場合のあ ることが示されたが，何故そうなのか理由は明らかでない. そのような場合, 固有拡散係数がどらなっているのか調べる ことは，機構を解明する手がかりになるのではないかと考 え，カーケンドール効果の実験を行った。ただし，マーカー・ の移動距離の測定から固有拡散係数を決定する Darkenの解 析 ${ }^{(2)}$ は拡散対の内に異相界面が存在する場合まで考慮された ものではないので，そのような拡散対に拈けるマーカー移動 の実験を行って Darken の解析法をそのまま用いることは適 当でないかもしれない。すなわち，異相界面を有する相互拡 散では異相界面で空孔の湧出や消失があるであろうし，それ による格子面の生成や消滅も起こり得る(16)(21)(22). しかし, 得られた結果は異相界面の存在による特異性が現れたものと 考えることもできる.

通常のカーケンドール効果の実験では, 拡散対の接合面に マーカーを挿入し，拡散によるマーカー移動を測定すること によって, 拡散後のマーカー面濃度に打ける固有拡散係数を 決定する。したがって, 固有拡散係数の濃度依存性を知るた めには, 拡散対の終端濃度を種々に变えた数多くの拡散対を 作製して実験を行ら必要がある.これに対して, マルチプル マーカー法は一つの拡散対から広い濃度範囲にわたる固有拡 散係数を決定できる. その理論は Levasseur と Philibert ${ }^{(23)}$ によって提案され, Cornetらによって1970年代初期に出来 上がった(24)(25). Heumann とGrundhoff(11) は箔の間にマー カーを入れ，箔を多数重ねて $\mathrm{Cu} / \mathrm{Ni}$ 拡散対を作製して実験 を行い, この解析法を適用した。しかし，この方法は拡散中 の䈱の再結晶がマーカー移動に影響する可能性がある. 我々 はバルク $\mathrm{Ni}$ 片の間に酸化ク口ム粉を入れたものと $\mathrm{Cu}$ との 拡散対を作製し，固有拡散係数を広い濃度範囲で連続的に決 定することに初めて成功した ${ }^{(26)}$. この方法を $\mathrm{Au} / \mathrm{Fe}$ に適用 し， $1133 \mathrm{~K}$ で $1.79 \times 10^{5} \mathrm{~s}$ 拡散させたものを図 7 に示す(27). 上方が $\mathrm{Fe}$ 側, 下方が $\mathrm{Au}$ 側である. マルチプルマーカーと 
してアルミナ粉が Fe 側に接合面に $45^{\circ}$ の角度で入っている. 相界面は $\mathrm{Fe}$ 側に移動し，マルチプルマーカ一の $\mathrm{Au}$ 側への 移動が観察される.カーケンドール面にタングステン線が見 える。このよらなマルチプルマーカー移動からAu拈よび $\mathrm{Fe}$ の固有拡散係数を1133から $1263 \mathrm{~K}$ で決定した.

図 8 は固有拡散係数の比 $D_{\mathrm{Au}} / D_{\mathrm{Fe}}$ の濃度依存性を示した ものである(28). 1203 と $1263 \mathrm{~K}$ では拡散対は $\mathrm{Au} / \gamma-\mathrm{Fe}$ であ り， $D_{\mathrm{Au}} / D_{\mathrm{Fe}}$ の值は1.0から1.1でほとんど濃度に依存しな い。ひに対して，1063から $1133 \mathrm{~K}$ では拡散対は $\mathrm{Au} / \alpha$ $\mathrm{Fe}$ である。 $D_{\mathrm{Au}} / D_{\mathrm{Fe}}$ の值は異相界面に近づく棌ど大きく， 温度が高いはど上昇する。図 4 亿示した相互拡散係数の濃 度および温度依存性を考光あわせると, $\mathrm{Au} / \alpha-\mathrm{Fe}$ 拡散対で は $\mathrm{Au}$ 側の桩散性に対応寸る空孔流が $\alpha-\mathrm{Fe}$ 側から $\mathrm{Au}$ 側

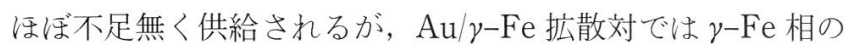
拡散性が著しく小さいために, Au 側の拡散性に対応する空 孔流を $\gamma-\mathrm{Fe}$ 相から $\mathrm{Au}$ 固溶相へ供給することができず, $D_{\mathrm{Au}}$ の減少となって, 㘠 8 に示されたよらに $D_{\mathrm{Au}} / D_{\mathrm{Fe}}$ の値が 界面近くでも低いものと思われる。 $\gamma$ - Fe 相から $\mathrm{Au}$ 固溶相 への空孔流の不足は $\mathrm{Au} / \gamma-\mathrm{Fe}$ 拡散対の拡散に遅滞を生じさ

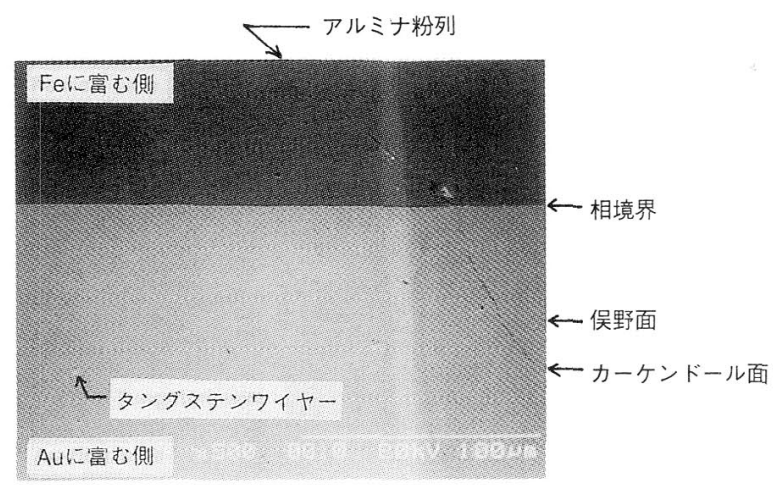

図 7 マルチプルマーカーを挿入し $1133 \mathrm{~K}$ にて $179 \mathrm{ks}$ 拡散させた後の $\mathrm{Au} / \mathrm{Fe}$ 拡散対の SEM 像.

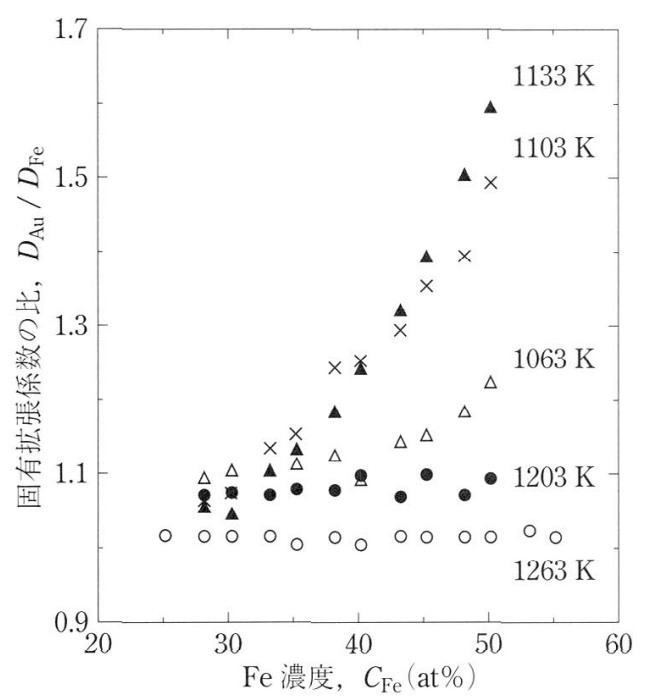

図 8 固有拡散係数の比 $D_{\mathrm{Au}} / D_{\mathrm{Fe}}$ の濃度および温度依 存性.
せ，図４に示したよらに $\mathrm{Au}$ 固溶相の全濃度域において相互 拡散係数が減少したものと考えられる。

\section{Au-Ni 合金における相互拡散}

さて, 拡散性に著しい差異のある金属間の相互拡散に执い ては, 俣野の方法や Darkenの関係式に矛盾が生じることを 示した。 しかし, $\mathrm{Au} / \mathrm{Fe}$ 拡散対には異相界面が存在するの で, それが原因であるとする可能性もある。そこで, 全率固 溶体を形成する 2 元合金で拡散性に著しい差異のあるもの について相互拡散の実験を行らことにした。

Au-Ni 2 元系は $1083 \mathrm{~K}$ 以下では二相分離するが，1083 と $1228 \mathrm{~K}$ の間では全率固溶体を形成する。また，Auと Niで はそれぞれの自己桩散係数に約 3 桁の差がある。Au-Ni 合 金については1957年に発表された Reynolds らの研究があ り (3), 教科書にも良く引用されている。最近, van Looのグ ループ(29) が我々とは別の観点からこの系の相互拡散の検証 実験を行っている。図 9 は全率固溶温度域の1103から 1173 Kに打忊る相互拡散係数の濃度依存性を示したものであ る(30). $\mathrm{Au} / \mathrm{Au}-36 \mathrm{at} \% \mathrm{Ni}$ 拡散対より得られた相互拡散係数 を $\mathrm{Ni}$ 濃度ゼロに外抻した值は, Darkenの関係式の予測通 り, $\mathrm{Au}$ 中の $\mathrm{Ni}$ の自己拡散係数に一致する。しかし, $\mathrm{Au} / \mathrm{Ni}$ 拡散対から得られた相互拡散係数の值は $\mathrm{Ni}$ 濃度全体にわた って低い。このように $\mathrm{Au}-\mathrm{Ni}$ 全率固溶体においても, $\mathrm{Au}-$ $\mathrm{Fe}$ 合金の相互拡散において見出された矛盾が見られる。し たがらて，その原因は異相界面が存在することによるもので はなく，先に指摘したように，拡散対を構成する金属間の拡 散性の著しい差によるものであるう。ただし，Ni側で相互

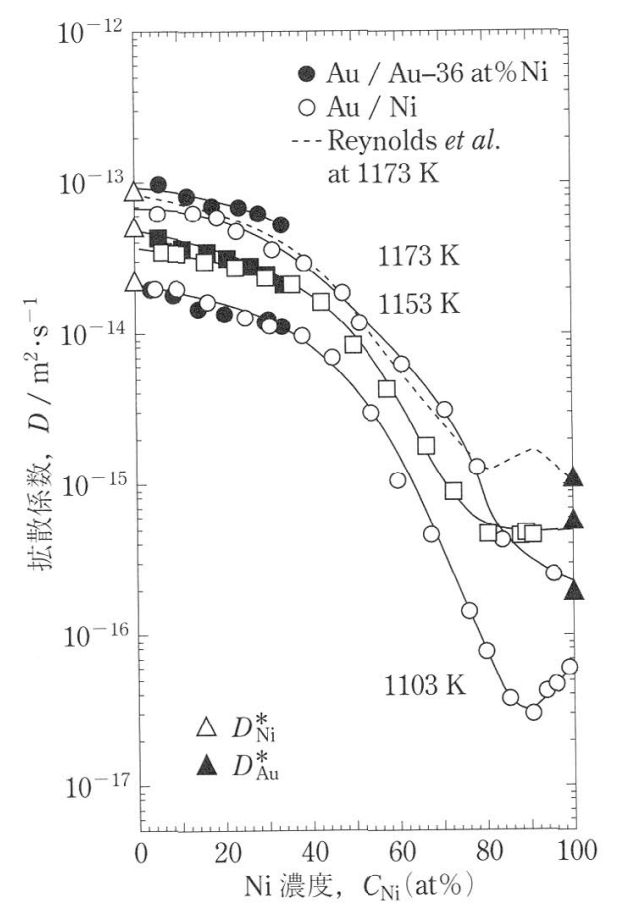

図 9 二つの異なる $\mathrm{Au}-\mathrm{Ni}$ 系拡散刘から決定された相 互拡散係数の濃度依存性. 
拡散係数が $\mathrm{Ni}$ 中の $\mathrm{Au}$ の自己拡散係数の值に一致していな いが， $\mathrm{Ni}$ 側に扔いては梶原ら ${ }^{(31)}$ が $\mathrm{Cu} / \mathrm{Ni}$ 拡散対の組織観察 から指摘しているよらに Ni の再結晶の問題も関係している ものと思われる. Au-Ni 系の Ni 側についての議論は本題か らはずれるので, ここではこれ以上ふれない。

\section{6. 高水素圧力下における Au-Fe 合金の相互拡散}

以上のように, $\mathrm{Au} / \mathrm{Fe}$ 拡散対および $\mathrm{Au} / \mathrm{Ni}$ 拡散対を用い た場合に得られる相互拡散係数の值は $\mathrm{Au}$ 側固溶体内の拡散 対から得られるものに一致しないことが明らかになり，その 原因は拡散対を構成する金属間の拡散性に著しい差があるた めであるとの結論に至った. これらの系の拡散は空孔機構に よるものであるから, 拡散性の差を小さくするには Fep $\mathrm{Ni}$ の拡散係数を大きくすればよい。一つの方法はこれらの 金属の空孔濃度を増加させることである．最近の深井(32)(33) の研究によれば, 高水素圧力下に金属を拈くと, 水素の侵入 に伴って空孔が極めて多量に導入される。しかも都合の良い ことに, Fe や Ni に多量に空孔が導入される条件でも Au に はそれほどでないことが予測される(34).そこで, $\mathrm{Au} / \mathrm{Fe}$ お よび $\mathrm{Au} / \mathrm{Au}-37 \mathrm{at} \% \mathrm{Fe}$ 拡散対の高水素圧下に拈ける拡散実 験を行った (35).

図10は静水圧下に拈ける相互拡散係数を示したものであ る. 静水圧下では拡散は一般に抑制される。 $\mathrm{Au}-\mathrm{Fe}$ 合金の 相互拡散に抢いても，5 $\mathrm{GPa}$ の静水圧において相互拡散係数 は Au 固溶相で $1 / 10$ に低下し， $\gamma-\mathrm{Fe}$ 相では $1 / 20$ に低下する. ここで注目すべきことは $\mathrm{Au} / \mathrm{Au}-37 \mathrm{at} \% \mathrm{Fe}$ 拡散対による相
互拡散係数と $\mathrm{Au} / \gamma-\mathrm{Fe}$ 拡散対による相互拡散係数との差が $5 \mathrm{GPa}$ の静水圧をかけることによって拡大していることであ る. すなわち, $\mathrm{Fe}$ 側の拡散の低下が大きいために, $\mathrm{Au}$ 側 で拡散対による差異が更に大きくなっている. 図11は高水素 圧力下に括ける相互拡散係数を示したものである. 予期した ように相互拡散は促進している. $5 \mathrm{GPa}$ 静水圧の場合よりも $5 \mathrm{GPa}$ の水素下では相互拡散係数は $\mathrm{Au}$ 側で 4 倍に, Fe 側 で50倍に増加した。しかも，拡散対による相互拡散係数の 差は減少している。これは正に Fe 側の空孔濃度の非常に大 きな増加によって, $\gamma$-Fe 側から $\mathrm{Au}$ 側への空孔流が増大し たことによるものである。

図12はこれらの結果をまとめたもので， $\mathrm{Au} / \mathrm{Au}-37 \mathrm{at} \% \mathrm{Fe}$ 拡散対による相互拡散係数に対して $\mathrm{Au} / \boldsymbol{\gamma}-\mathrm{Fe}$ 拡散対による 相互拡散係数の比を $\mathrm{Au} / \mathrm{Fe}$ 拡散対の両端の拡散係数の比に 対してプロットしたものである. 縦軸の相互拡散係数の比は 12 at\% Fe 濃度に拈ける值を示した。拡散対の両端の拡散係 数の差が小さくなるとともに, 拡散対による相互拡散係数の 差が減少することがわかる. すなわち, 拡散対の終端の拡散 性の差が小さい場合は, 俣野の方法の適用に問題はない。

Fick の第 2 法則から俣野の図式解法に至るまで, 数学的 に問題とされる点はない。しかし，A-B 2 元合金の相互拡 散に拈いて俣野の解法は 1 成分のみを対象にしているが, 相互拡散は A, B 両原子が関与し, そのジャンプ過程に空孔 が介在するので, それら三種類の流束を考慮しなければなら ない. 俣野の時代には空孔の意義は認識されていなかった。 空孔は拡散領域で生成·消隇し, それに伴い格子面も生成· 消滅する。このような空孔の非保存性のために Darken も十

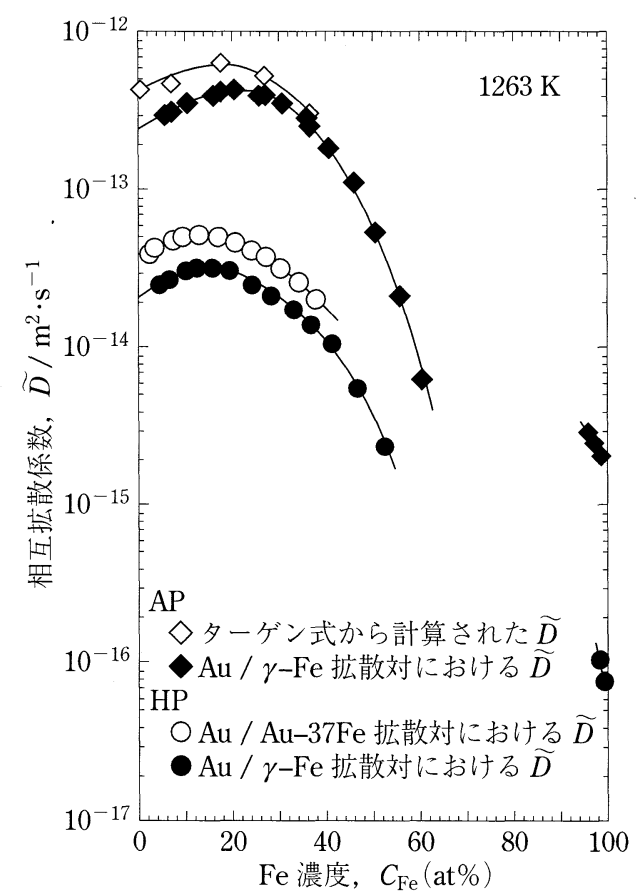

図10 二つの異なる $\mathrm{Au}-\mathrm{Fe}$ 系拡散対から静水圧下に拉 いて決定された相互拡散係数の濃度依存性, $\mathrm{AP}$ : 常圧下, HP : 静水圧下.

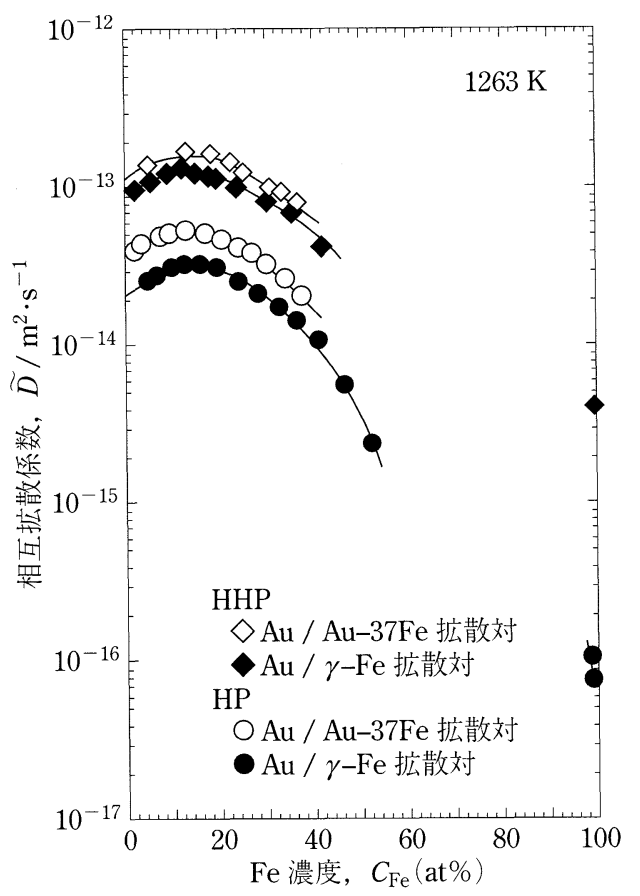

図11 二つの異なる $\mathrm{Au}-\mathrm{Fe}$ 系拡散対から高水素圧下に 扣いて決定された相互拡散係数の濃度依存性, $\mathrm{HHP}$ : 高水素圧下, HP : 静水圧下. 


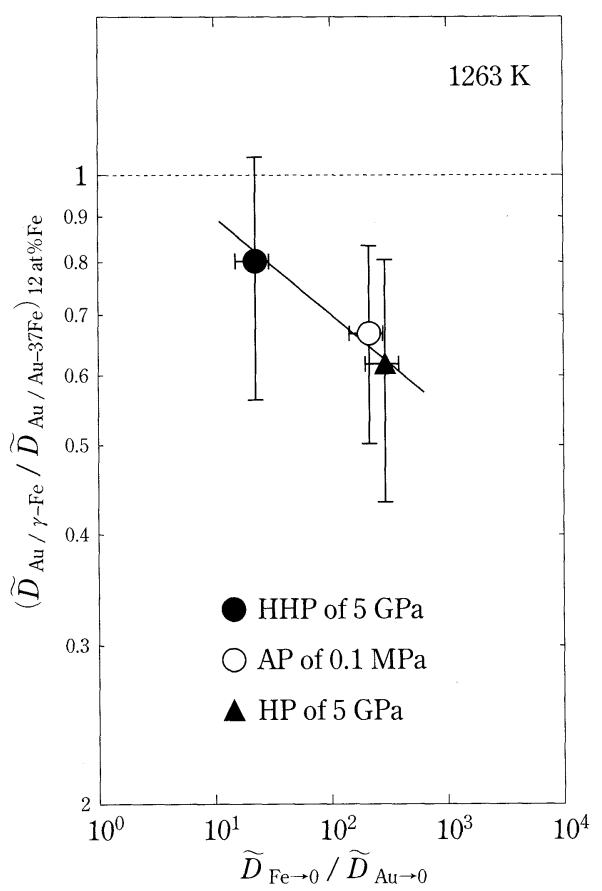

図12 Au/Au-37 at \% Fe 拡散対による相互拡散係数に 対して $\mathrm{Au} / \gamma-\mathrm{Fe}$ 拡散対による相互拡散係数の比 を $\mathrm{Au} / \mathrm{Fe}$ 拡散対の終端の拡散係数の比に対して プロットしたもの, HHP : 高水素圧下, AP：常 圧下, HP: 静水圧下.

分に取り扱い得なかったのではないだろらか。

\section{7. おわりに}

相互拡散の解析の基本的枠組は Fick の法則を展開して, 俣野と Darkenによって与えられた. その後, 多くの研究者 によって理論の改良がなされたが，拡散が空孔機構によるも のであり，その空孔は拡散対内で生成・消隇する非保存量で あるため, 取り扱いが単純でない。異相界面の存在は拡散の 進行に相変態を伴らため, 取り扱いを更に困難にする(36). 他方，放射性同位元素を用いたトレーサー拡散の実験技術は 最近益々向上している。相互拡散の実験に打いても, EPMA や分析電顕などの進歩によって拡散領域の精密な濃 度分析が可能になり, 相互拡散係数や固有拡散係数の值が詳 細に得られるよらになった。相互拡散の解析法の不備は, こ らした実験技術の進歩によって，明らかにされてきたもので ある、これからは, 空孔流束を考慮した現象方程式に立ち返 って，新しい解析法が生まれることを期待したい。

相互拡散の解析法の問題点について度々議論していただい た九州工業大学 大西正已名誉教授に感謝する．高圧装置の 使用に便宜を計られた東北大学 岡田益男教授に感謝する. 本研究は科研費 $(09450230,10136203)$ 扎よび1999年度笹川 科学研究助成によって推進されたものである.

\section{文献}

(1) C. Matano: Japanese J. Phys., 8(1933), 109-113.

(2) L. S. Darken: Trans. AIME, 175(1948), 184-201.

( 3 ) J. E. Reynolds, B. L. Averbach and M. Cohen: with an Appendix by J. E. Hilliard: Acta Met., 5 (1957), 29-40.

（4）小岩昌宏：末てりあ，38(1999), 798-802.

(5) F. Sauer and V. Freise: Z. Electrochem., 66 (1962), 353-363.

(6) A. D. Smigelskas and E. O. Kirkendall: Trans. AIME, 171 (1947), 130-142.

( 7 ) J. R. Manning: Acta Metall., 15 (1967), 817-826.

( 8 ) Th. Heumann: J. Phys. F, 9(1979), 1997-2010.

（9）孫鳳根，佐野忠雄：日本金属学会誌，41(1977), 11131121.

（10）大西正已，下㠃敏唯：日本金属学会誌，46(1982)，1-8.

(11) Th. Heumann and K. J. Grundhoff: Z. Metallkd., 63(1972), 173-180.

(12) B. D. Clay and G. W. Greenwood: Philos. Mag., 25(1972), 1201-1211.

(13) K. Ouchi, Y. Iijima and K. Hirano: Titanium '80 Science and Technology, ed. by H. Kimura and O. Izumi, AIME, New York, (1980), p. 569-576.

(14) K. Hirano and Y. Iijima: Diffusion in Solids: Recent Developments, ed. by M. A. Dayananda and G. E. Murch, The Metallurgical Society AIME, Warrendale, PA, (1985), p. 141-166.

（15）下㠃敏唯，大西正已：日本金属学会誌，42(1978), 10831089.

(16) M. Onishi, F. Furukawa and T. Shimozaki: Mater. Sci. Forum, 204-206 (1996), 215-220.

(17) W. Jost: Diffusion in Solids, Liquids, Gases, revised ed., Academic Press, New York, (1960), p. 75.

(18) W. Jost: Z. Phys., 127(1950), 163-167.

（19）西澤泰二，千葉 帠：日本金属学会誌，34(1970), 629-637.

(20) Y. Iijima, K. Hirano, T. Ohzeki and K. Suzuki: DIMETA-82 Diffusion in Metals and Alloys, ed. by F. J. Kedves and D. L. Beke, Trans. Tech. Publications, Switzerland, (1983), p. 401-404

(21) M. Onishi, K. Miyake, Y. Wakamatsu and T. Shimozaki: Defect Diff. Forum, 95-98(1993), 561-572.

（22）大西正已，若松良徳，下㠃敏唯：まてりあ，33(1994), 940947.

(23) J. Levasseur and J. Philibert: Phys. Status Solidi, 21(1967), $\mathrm{K} 1-\mathrm{K} 4$.

(24) J. F. Cornet and D. Calais: J. Phys. Chem. Solids, 33(1972), 1675-1684.

(25) J. F. Cornet: J. Phys. Chem. Solids, 35(1974), 1247-1252.

(26) Y. Iijima, K. Hirano and M. Kikuchi: Trans. JIM, 23(1982), 19-23.

(27) Y. Iijima, K. Funayama, T. Kosugi and K. Fukamichi: Philos. Mag. Lett., 74 (1996), 423-428.

(28) Y. Iijima, T. Kosugi and K. Fukamichi: Defect Diff. Forum, 143-147(1997), 499-504.

(29) M. J. H. van Dal, M. C. L. P. Pleumeekers, A. A. Kodentsov and F. J. J. van Loo: J. Alloys Comp., 309 (2000), 132-140.

(30) T. Sugiyama, Y. Yamazaki and Y. Iijima: Proc. Int. Conf. Solid-Solid Phase Transformations '99(JIMIC-3), ed. by M. Koiwa, K. Otsuka and T. Miyazaki, The Japan Inst. Metals, (1999), p. 513-516.

(31) Y. Kawanami, M. Nakano, M. Kajihara and T. Mori: Mater. Trans., JIM, 39(1998), 218-224.

（32）深井 有, 黒川善文, 平岡寛勝 : 日本金属学会誌, 61(1997), 663-670.

（33）深井 有：日本物理学会誌， 55(2000), 685-692.

(34) H. Sugimoto and Y. Fukai: Acta Metall. Mater., 40(1992), $2327-2336$.

(35) Y. Yamazaki, H. Kakuta, M. Okada and Y. Iijima: Defect Diff. Forum, 194-199(2001), 1069-1074.

（36）大西正已, 李 賛 揆, 尹 在 弘, 下㠃敏唯 : 日本金属学会誌, 62 (1998), 505-509. 